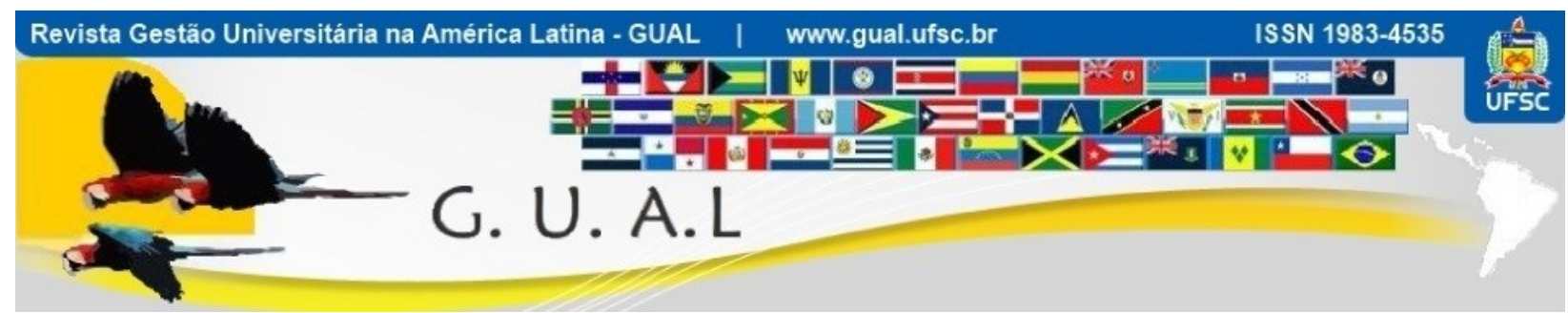

DOI: http://dx.doi.org/10.5007/1983-4535.2019v12n3p196

\title{
SPIN-OFF FLOURISHING: A NEW WAY FOR ENTREPRENEURSHIP EDUCATION THROUGH EXPERIENTIAL LEARNING PROCESSES
}

\section{CULTIVANDO SPIN-OFFS: UMA NOVA MANEIRA DE ENSINAR EMPREENDEDORISMO A PARTIR DOS PROCESSOS DE APRENDIZAGEM EXPERIENCIAL}

\author{
Artur Tavares Vilas Boas Ribeiro, Mestre \\ https://orcid.org/0000-0002-0951-7191 \\ artur.tavr@gmail.com \\ Universidade de São Paulo | Faculdade de Economia, Administração e Contabilidade \\ São Paulo | São Paulo | Brasil \\ Patrícia Viveiros de Castro Krakauer, Doutora \\ https://orcid.org/0000-0003-4262-1297 \\ pkrakauer@terra.com.br \\ Centro Universitário Campo Limpo Paulista | Mestrado Profissional em Administração \\ São Paulo | São Paulo | Brasil \\ Eduardo Bonilha, Mestre \\ https://orcid.org/0000-0002-8329-693X \\ edubonilha@gmail.com \\ Universidade de São Paulo | Faculdade de Economia, Administração e Contabilidade \\ São Paulo | São Paulo | Brasil \\ Guilherme Ary Plonski, Doutor \\ http://orcid.org/0000-0002-8949-4363 \\ plonski.usp@gmail.com \\ Universidade de São Paulo | Faculdade de Economia, Administração e Contabilidade \\ São Paulo | São Paulo | Brasil
}

Recebido em 26/setembro/2018

Aprovado em 07/junho/2019

Publicado em 02/setembro/2019

Sistema de Avaliação: Double Blind Review

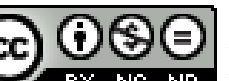

Esta obra está sob uma Licença Creative Commons Atribuição-Uso.

Revista GUAL, Florianópolis, v. 12, n. 3, p. 196-215, setembro-dezembro 2019 www.gual.ufsc.br 


\begin{abstract}
This study analyzes the emergence of an experiential learning program focused on final undergraduate projects in Engineering and Applied Sciences. The analyzed program is oriented to provide active learning experiences in which students were responsible for directing their final project towards transforming them into nascent technology-based companies. This exploratory and qualitative case study focused on the students' analysis of (i) the perception about the learning processes, (ii) the motivation to continue with the business, (iii) the engagement with knowledge involved in the final project (iv) the relationship with the technology-based entrepreneurship subject. Seeking to present new frontiers in experiential learning, the findings of the present paper show the positive impact of experiential learning on students' motivations and results when it comes to creating a technology-based venture, reinforcing the premises of Kolb and others. This study contributes by providing a detailed description of an entrepreneurship education program in Brazil, and also by offering more arguments towards the use of experience-based learning in undergraduate studies.
\end{abstract}

Palavras-chave: Entrepreneurship. University Startups. Experiential Learning. Startups. Undergraduate Teaching.

\title{
RESUMO
}

Este estudo analisa o surgimento de um programa de aprendizagem experiencial focado em projetos finais (TCC's) de graduação em Engenharias e Ciências Aplicadas. O programa analisado volta-se à oferta de experiências ativas de aprendizado - nas quais os alunos são responsáveis por direcionar seu projeto final de modo a transformá-los em empresas nascentes de base tecnológica. Este estudo de caso exploratório e qualitativo deu foco à análise dos alunos sobre (i) a percepção sobre os processos de aprendizagem, (ii) a motivação para continuar com o negócio, (iii) o envolvimento com o conhecimento envolvido no projeto final (iv) a relação com o tema do empreendedorismo de base tecnológica. Buscando apresentar novas fronteiras na aprendizagem experiencial, as conclusões do presente artigo mostram o impacto positivo da aprendizagem experiencial nas motivações de alunos, bem como seus resultados acerca do processo de criação de empresas de base tecnológica, reforçando as premissas de Kolb e outros. Este estudo contribui ao fornecer uma descrição detalhada de um programa de educação para o empreendedorismo no Brasil, além de oferecer mais argumentos para o uso da aprendizagem baseada na experiência em estudos de graduação.

Keywords: Empreendedorismo. Startups Universitárias. Aprendizagem Experiencial. Startups. Ensino de Graduação. 


\section{INTRODUCTION}

While innovative entrepreneurship, especially focused on the creation of hyper-growth technology-based companies, has become one of the central pillars in the quest for reinventing economies and generating wealth, the attention given to the role of the university has grown (Guerrero, Urbano \& Fayolle, 2016). The main argument is that universities can provide a lot of resources to an entrepreneurial ecosystem (human capital, scientific production, technological advances, etc.) and also orchestrate the creation of vibrant environments for the emergence of entrepreneurship (Isenberg, 2010; Etzkowitz, 2011).

In Brazil, this growth has also occurred in the demand for the stimulus to entrepreneurship by various others agents, such as public policies, private efforts, strengthening academic environments for innovation and other actions. This gave an emphasis to the country in studies as the Global Entrepreneurship Monitor, which points Brazil as the highest rate of entrepreneurship among BRICS (Singer et al., 2015). More specifically, São Paulo stood out in the Global Startup Ecosystem Ranking as the main ecosystem in Latin America and twelfth in the world (Hermann et al., 2015).

Regarding the university's role in entrepreneurship ecosystems, there's a strong highlight worldwide, however, in Brazil, there are criticisms about the performance of this agent. Levin (2015) presents the critique of foreign venture capitalists on the challenges of investing in Brazil, with an emphasis on the startup staff formal training being the largest bottleneck in the nation. Entrepreneurship studies about Brazilian Universities (Endeavor, 2012) also corroborate to this affirmation - calling attention to the high attraction of the undergraduate students in entrepreneurship, but with a low direction of the university to support in that sense.

In this context, Brazilian universities have several possible horizons for engaging with entrepreneurship training and may even develop its own entrepreneurial ecosystem, organizing their agents in order to foster such movement in their environment (Lemos, 2012). One of the possible unfolding pointed is the improvement of teaching tools and processes, which can be thought of in a different way when it comes about entrepreneurship training being the experiential learning approach an effective solution (Krakauer, 2014). Krakauer points out that there can be positive gains in the formation of entrepreneurs by proposing processes that involve the interaction of the individual with their environment, in order to stimulate greater connections and relations with learning (Kolb, 1984; Dewey, 1916). 
Considering the circumstance presented above, the current research seeks to evaluate experiential learning mechanisms that were created to foster technology-based entrepreneurship. It is a Brazilian entrepreneurship support program focused on engineering and applied sciences undergraduate students whose graduation work has the potential to become new technology-based businesses.

The paper is structured as it follows: after a theoretical review on (a) the university's role in entrepreneurship ecosystems, (b) the generation of academic spin-offs, (c) experiential learning and entrepreneurship teaching, the article presents a description of the study object (Academic Working Capital Program). Following the description, we have the results and data analysis, finally culminating in the conclusions, limitations, and opportunities for future studies. As a contribution, this study could indicate theoretical and practical paths for entrepreneurship teaching in universities, fostering the training of potential entrepreneurs and the generation of innovative companies.

\section{RESEARCH CONTEXT AND OBJECTIVES}

Highlighting the importance of universities in entrepreneurship ecosystems and the role of new teaching processes, some questions arise in the midst of the researchers' experiences involving learning activities. The training activity in question was the Academic Working Capital (AWC) Program, developed by the Tim Institute with the support of the Polytechnic School of the University of São Paulo (Poli-USP) and the USP Entrepreneurship Society. A program focused on financing and supporting final undergraduate projects of engineering and applied sciences students, offering a structured process oriented towards market interactions and business development to create technology-based companies with their final projects.

The program was distinguished by the pioneering approach that seeks an interface between technical works and entrepreneurship ecosystems, being considered a good reference to be studied in the context of new methods of experiential learning. Thus, this study aims to investigate the AWC students' perceptions about the experiential learning mechanisms exercised in the proposed activities of the program. 
In this way, the present study unfolds in the following objectives:

- Primary: to analyze students' perceptions about experiential learning mechanisms in entrepreneurship, applied to the context of final undergraduate projects.

- Secondary: (i) describe the processes, methods and tools used for teaching entrepreneurship to students in the senior period; (ii) raise students' perceptions regarding the maturation in the relationship with their final projects; (iii) evaluate, in the students' viewpoint, the methods and tools used, the learning results achieved, as well as their future perspectives on the creation of innovative companies.

\section{LITERATURE REVIEW}

Aligning with the introduction elements presented above in this study, several authors defended the university's role in entrepreneurship ecosystems for economic development (Guerrero, Urbano \& Fayolle, 2016; Loi \& Guardo, 2015; Vauterin, Linnanen \& Michelsen, 2013). Glaesser \& Kerr (2010) and Kon et al. (2014) emphasize that the most important ecosystems are those with strong relationships with institutions of higher education, such as the cases of Silicon Valley and Israel. Entrepreneurial ecosystems can be understood as a set of conditions that, acting in a collaborative manner, stimulate high-level entrepreneurship (Regele \& Neck, 2012). For Isenberg (2011), the ecosystem is composed of six major elements: market, public policies, financial structure, cultural patterns, support mechanisms and human capital. Universities strongly contributing to this last element. For entrepreneurs, universities can also help offering (i) direct support to entrepreneurial students; (ii) infrastructure; (iii) high quality human capital as first employees; (iv) good relationships with industry and government; (v) network with technology experts (Rasmussen \& Wright, 2015; Feld, 2012; Isenberg, 2011; Regele \& Neck, 2012).

The approaches to education go through several theory streams. According to Santos (2005) universities still possess the classic view of the teacher as a figure in a classroom that makes the student a passive subject that accumulates information. This is a framework in which the transmission of knowledge rests essentially with the teacher, almost without interference from the students and their interests.

With the development of new approaches, it came an approximation of concepts in which there is an interaction between the subject and the object. In entrepreneurship education, some approaches aligned with this perspective are presented in Krakauer's (2014) doctoral thesis, in which she proposes an experiential method to teach entrepreneurship based 
on the theory of experiential learning proposed by Kolb (1984). For the author, this approximation with issues of subject-object interaction gains more attention in the cognitive (or "Piagetian") theory, a proposal that treats learning as a transformation of existing mental structures, resulting from interactions between the subject and the object. Thus, there is a greater emphasis on the role of learning by experiences, directly linked to the schools of Dewey, Lewin and Piaget, in which the tension and conflict arising from the interaction of the individual with the environment in which he is inserted reflects directly in the processes of learning (Kolb, 1984).

In relation to the educators' role in the experiences-centered environments, Blikstein (2008) argues that it is no longer to push an implementation of a definite script, but to facilitate student interactions with the context in which they are, in order to meet the metaphor of the knowledge as a network proposed by Machado (2004) that advocates the centers of interest of students in a classroom.

Based on the experience-based approach, models related to entrepreneurship-based learning are becoming more present in the academic literature in which the following pillars can be highlighted: interaction with context, shared meanings, skills and attitudes development, experience and its transformation process and the experience centered on specific branches. Cooper, Bottomley \& Gordon (2004), for example, presents the evolution of entrepreneurship education - starting at classic lectures model and going to experience based approaches such as doing projects inside newborn enterprises.

When it comes about teaching entrepreneurship, its possible to see a lot of branches: opportunity recognition competence, creativity skills, business development, technological aspects and others diverse aspects. It is a matter of seeking to advance in the understanding of specific methodologies to teach a thematic that embraces several theoretical perspectives and has variants in its conceptualization existing in common sense as well as scientific knowledge. This complexity puts the emergence of experiential learning as a possibility in the frontier of the knowledge on entrepreneurship education, with some authors gaining more deep comprehension on it (Rae \& Carswell, 2000; Solomon, Duffy \& Tarabishy, 2002; Zampier \& Takahashi, 2011; Cooper, Bottomley \& Gordon, 2004; Corbett, 2005).

Built on this brief theoretical review, its possible to formalize some constructs:

Premise 1: universities are an important element of entrepreneurship ecosystems, bringing economic development through academic startups that 
can be created with well-designed processes and solid institutions in its environment.

Premise 2: experiential learning can be a healthy way of teaching entrepreneurship, with formal processes and approaches to the relationship between students and the studied object.

With this constructs, the present study came with some questions that oriented the whole research work:

- Based on a premise that entrepreneurship experiential teaching processes dialogues with the processes of startups creation, how can it be a startup oriented process that has its roots in experiential learning methods?

- What is the impact of entrepreneurship experiential learning in the students' relationship with their undergraduate subjects?

- What is the impact of entrepreneurship experiential learning and entrepreneurial intentions after graduation?

\section{INSTRUMENTS AND METHODS}

This is an exploratory research that seeks to investigate AWC students' perceptions about the program experience. In order to achieve this main objective, a case study with triangulation of data was chosen, considering that it is a method that allows the use of a great variety of evidence, such as documents, artifacts, interviews and observations (Yin, 2005).

It is understood that the technique of data triangulation is one of the ways to seek confirmation of data in research of this nature (Eisenhardt, 1989) and to increase the accuracy of the data analysis, being able to be realized through the use of diverse, different methodologies of data collection or even through the observation of different researchers (Flick, 1992). Thus, the following research strategies were adopted to compose the desired triangulation: (i) documentary research about the AWC Program; (ii) participant observation by two researchers (program mentors) and (iii) survey with the students participating in the program.

The object of study (unit of analysis) is the AWC - Academic Working Capital Program, which was developed focused on last year students of engineering courses with the objective of supporting with knowledge and financial resources the development of startup companies based on final projects knowledge. Two of the authors acted as mentors of the AWC Program, actively participating in all activities and supporting students in the decisions and development of products and business models. This participation allowed the direct 
observation of the facts and the monitoring of the application of teaching activities to the students.

According to the research strategies proposed for triangulation, the following procedures were used to collect data:

1. Data collection from secondary sources (documentary): documentary research was carried out through support materials and AWC Program websites and the Tim Institute.

2. Data collection through participant observation: the observation was direct and participatory, aiming to obtain data in loco for the description of the steps designed by the organizers of the program. The steps recommended by Queiroz et al. (2007): (i) insertion of the researcher into the social environment; (ii) data collection and recording of information in the field diary; and (iii) systematization, organization and analysis of the data obtained.

3. Survey: elaboration and application of a structured questionnaire to the participants of the AWC Program, considering the objectives of the study and the experiences lived by the students;

And for the data analysis were the following procedures:

1. Comparative analysis of the secondary data with the data obtained with participant observation, culminating in the detailed description of the stages of the program that will be presented in topic 5 .

2. Quantitative analysis of the data obtained with the application of the questionnaire, being calculated percentages, standard deviation and rankings, when this was the case. Such an analysis will be presented in topic 6 of this article.

3. Analysis of the results obtained with the quantitative survey in the light of the theoretical reference and the description made.

The questionnaire was composed of 40 closed questions, using 5 points scale (grades 1 to 5), being grade 1 for very low / not important, and grade 5 for very high / very important. To minimize the effects of arbitrary weighting in scale analysis, it is understood that the students had more homogeneous characteristics (similar life moment, ages and training) and that the analysis was complemented with perceptions of the participating researchers. The questions have been grouped into the following themes:

- Motivation to participate in the program

- Engagement with the final project development 
- Importance of the workshops

- Importance of the mentorship received

- Importance of the program over the project development

- General evaluation of the program

The program was started with 28 students, divided into 12 project teams (each project being a graduation project). There were 4 teams dropping out of the program, comprising 8 students in total. Of the 20 remaining students, it was possible to obtain the response of 18 students $(90 \%)$, which is a representative and sufficient sample for analysis and conclusions. The two students who did not respond are part of the same team that did not officially give up, but could not attend the workshops and investment fair for professional reasons. The questionnaire was applied during the investment fair, on the last day of the program, in printed forms and individually.

\section{DESCRIPTION OF THE ACADEMIC WORKING CAPITAL PROGRAM}

\subsection{ROOTS AND MOTIVATIONS}

The AWC Program was born out of the perception of a professor and a master's student at the Polytechnic School of USP (Poli-USP) together with an impact institute arm of the telecommunications company Tim (Instituto Tim) that invests in social programs focused mainly on science, technology and education. They believe that engineering students needed support to turn undergraduate final projects into innovative products and business (in Brazil, the final project is a very important element of engineering courses). For them, ideas should come off the paper, but there were several difficulties involved in the business creation process, such as obtaining resources for prototype development or acquiring specific management knowledge. The program was also inspired by a similar project carried out by Tim in Italy to startups supporting.

\subsection{PROGRAM STRUCTURE}

As already pointed out, the AWC Program seeks to encourage the creation of innovative technology-based companies through the graduation projects for engineering and science students. The purpose is to support students with financial resources to develop 
product prototypes, as well as provide advice, knowledge and methods for project improvement, business development and operations.

As a pilot for the first year of the project (2015), the AWC was announced and opened in the second quarter of 2015 to engineering students from the University of São Paulo, Federal University of Rio de Janeiro and Federal University of São Carlos. To participate, student teams should submit their product prototype proposals with their resource needs through the program website. The application had the following structure: objective and motivation; product presentation; business vision; state of the art knowledge involved; work plan; proposed budget; general data and qualifications of the team. Each team should have at least one engineering student linked to the final project and everyone should be from the same teaching institution.

AWC coordinators evaluated 40 received proposals and selected 12 that met the desired criteria - a perceived potential to generate viable products and businesses, of which nine were University of São Paulo teams, two from Federal University of Rio de Janeiro and one from Federal University of São Carlos, being 28 students in total.

With the chosen teams, the program was developed over a period of 6 months (July to December 2015), based on the following activities:

- Presential Workshops: full-day events with speakers, product design and business modeling experts, with moments for discussions and teamwork;

- Product and Business Orientation: constant monitoring and mentoring to support the development of a product with sales potential and business model design (each team had one specific mentor);

- Financial Support: resources for the acquisition of materials, equipment or services necessary for the construction of a prototype or commercially viable product;

- Investment Fair: at the end of the program, event for product demonstration and networking with investors, accelerators, business people, experts and others.

\subsubsection{Workshop one}

The program began with the theme "Detailed Design and Construction". The workshop dynamics were basically lecturing with professors and design/innovation experts, followed by work within the teams for product and business development with subsequent sharing with other teams for feedback and suggestions. Students watched lectures about 
Engineering Design, Business Modeling, Lean Startup, Design Thiking, Prototyping and also with motivational talks from former students that created successful technology-based companies. Participants were challenged to (i) think and work on a first prototype, focused on the key functions and attributes of product quality, and (ii) to structure the business model based on the BM Canvas, always accompanied by program monitors. At the end of the day, prototypes of products and business models were shared within each cluster, in the form of drawings and presentations. The groups received feedback on the materials presented and guidelines for the last day, the open fair day with investors, experts, professors and others.

\subsubsection{Team monitoring}

For the team monitoring phase of the AWC Program, the teams were again divided into three clusters, with four teams each, according to criteria of product affinity and business model. Each cluster was attended by a dedicated monitor/mentor, all graduate students of the Faculty of Economics, Administration and Accounting of the University of São Paulo (FEAUSP) - a doctoral student in Business Administration and two masters in entrepreneurship and innovation. Purposefully, mentors were well-versed in innovative business models and management, but with limited knowledge in product engineering, since this was already covered by the advisor teacher of each final project (in Brazil, each final project need to have a full professor as the advisor). In addition, program coordinators or other experts could be called in case of doubts or need support for more technical or specific issues. Basically, it consisted of weekly and individualized contacts between mentors and teams, in person, over the phone or Internet (Skype), for product and business development guidelines, and biweekly reports delivery to the program, with status and project evolutions.

Along the way, as expected, there were some teams quitting, not being able to keep up with the program, not believing in the potential or not being so engaged in product and business creation. The exits were always discussed between the coordinators and mentors of the program, for the best decision and orientation with the teams. In total, 4 teams left the program at different times, out of the initial 12.

\subsubsection{Workshop two}

After the monitoring phase, the teams participated in a second workshop in December, with three days of preparation for the investment fair that was held on the last official day of 
the program. During the three days, the students participated in lectures, dynamics and discussions, and worked in the presentations and materials for the fair. Students attended lectures on investment horizons such as investment lines, public funding, crowdfunding, pitching, venture capital and angel investors.

To support students in preparing for the fair, financial resources were made available for the purchase of marketing and printing materials. The program also provided everyone with a high table with banquettes, a 40" LCD TV and a wooden panel to attach posters and banners. During the three-day workshop, three design students from the University of São Paulo were available to assist teams in creating branding, presentation templates and graphic materials.

\subsubsection{Investment Fair}

The Academic Working Capital Program 2015 was finalized with an investment fair, held on December 17, in a free event and open to the public, from 9:00 a.m. to 10:00 p.m., at the facilities of the Technological Park of the State of São Paulo, near the university campus. The opening was made in the auditorium by the coordinators of the program and the President of the Instituto Tim. Also spoke the Director of Business Development and Institutional Relations of Investe SP, an entity of the government responsible for the management of the Technology Park. Then everyone was able to attend the talk of one of the founders one of the main Brazilian startup about their trajectory and lessons learned. In the late afternoon, they also have the talk of the CEO of a venture capital and angel-investment company.

\section{DATA ANALYSIS AND RESULTS}

In order to evaluate students' perceptions about the experiential learning mechanisms applied in the teaching of entrepreneurship, as well as the methods and tools used, and the results achieved in the program, a questionnaire was delivered to all participants who were present at the investment fair. Table 2 shows the profile of these students.

The majority of the participating students is male $(88.9 \%)$. Although there is a predominance of men in engineering schools in Brazil, it is notorious that women have occupied more and more space in these courses and have a strong presence in the labor market, which shows an imbalance in this entrepreneurship program. More than $60 \%$ of the students in the program work and internship, which would denote a restriction on the 
dedication of time to complete work and the business project. However, more than half have at least two other partners and almost $70 \%$ of the students state that they spend at least 11 hours a week on the AWC and TCC projects (averaging more than 1:30 a day), demonstrating that there are resources and good dedication to product and business development. This is an important aspect, since that this kind of limitation is common in developing countries, and not that much in developed economies - a very actual research topic (Guerrero et. al., 2017).

Table 1 AWC Program Students profile

\begin{tabular}{|c|c|c|}
\hline Genre & Answers & $\%$ \\
\hline Men & 16 & $88,90 \%$ \\
\hline Women & 2 & $11,10 \%$ \\
\hline Total & 18 & $100 \%$ \\
\hline Course & Answers & $\%$ \\
\hline Mechatronics engineering & 10 & $55,6 \%$ \\
\hline Electrical engineering & 4 & $22,2 \%$ \\
\hline Physics engineering & 2 & $11,1 \%$ \\
\hline Production/industrial engineering & 1 & $5,6 \%$ \\
\hline Mechanical engineering & 1 & $5,6 \%$ \\
\hline Total & 18 & $100 \%$ \\
\hline Employed in other company? & Answers & $\%$ \\
\hline No & 10 & $62,5 \%$ \\
\hline Yes & 6 & $37,5 \%$ \\
\hline Total & 16 & $100 \%$ \\
\hline Number of partners in the project & Answers & $\%$ \\
\hline 2 people & 8 & $47,1 \%$ \\
\hline 3 people & 6 & $35,3 \%$ \\
\hline 4 people & 3 & $17,6 \%$ \\
\hline Total & 17 & $100,0 \%$ \\
\hline Weekly dedication to the project & Answers & $\%$ \\
\hline up to 5 hours & 2 & $15,4 \%$ \\
\hline 6 to 10 hours & 2 & $15,4 \%$ \\
\hline 11 to 20 hours & 6 & $46,2 \%$ \\
\hline 21 to 30 hours & 3 & $23,1 \%$ \\
\hline Total & 13 & $100,0 \%$ \\
\hline
\end{tabular}

Source: Research conducted by the author (2016). 


\section{SPIN-OFF FLOURISHING: A NEW WAY FOR ENTREPRENEURSHIP EDUCATION THROUGH \\ EXPERIENTIAL LEARNING PROCESSES \\ DOI: http://dx.doi.org/10.5007/1983-4535.2019v12n3p196}

Table 3 Initial motivation to participate in the AWC Program

\begin{tabular}{|l|c|c|c|c|}
\hline \multicolumn{1}{|c|}{ Motivation: Current decision to participate in AWC } & Mean & SD & Answers & Ranking \\
\hline Obtaining financial resources for the final project & 3,76 & 1,68 & 17 & 5 \\
\hline Business and product mentoring & 4,35 & 0,86 & 17 & 2 \\
\hline Knowledge/participation in the workshops & 3,82 & 1,13 & 17 & 4 \\
\hline Information exchange/networking & 4,47 & 0,62 & 17 & 1 \\
\hline Participation in the investment fair & 3,88 & 1,36 & 17 & 3 \\
\hline
\end{tabular}

Source: Research conducted by the author (2016).

Table 3 shows the initial motivations of students to participate in the AWC Program. By ranking, the first motivation was the exchange of information and networking, with a mean score of 4.47 , followed by business and product mentoring, also with a high mean score (4.35). Although with higher standard deviation, which shows divergences of opinion, obtaining funding for the final project is the motif with a lower mean (3.76).

Table 3 Engagement

\begin{tabular}{|l|c|c|c|}
\hline \multicolumn{1}{|c|}{ Engagement } & Mean & SD & Answers \\
\hline Engagement with the project before the AWC & 3,33 & 1,4 & 15 \\
\hline Engagement with the project after the AWC & 4,19 & 1,11 & 16 \\
\hline Advisors involvement with the project & 2,5 & 1,55 & 16 \\
\hline Intention to continue with the project & 4,53 & 0,72 & 17 \\
\hline Intention to build another enterprise & 3,69 & 1,08 & 16 \\
\hline Intention to dedicate to the business & 4,35 & 0,86 & 17 \\
\hline
\end{tabular}

Source: Research conducted by the author (2016).

From Table 3, it is possible to evaluate perceptions and results of the experiential learning of the students participating in the program. On mean, the mark for engagement in the completion of the project after completion of the program was 4.19 and more than $25 \%$ above the mark of engagement before the start of the program. The intention to continue with the project after the end of the program and to continue to focus on entrepreneurship, with mean scores of 4.53 and 4.35 , respectively, reinforcing the idea that the program and teaching methods were successful on the mission of arousing interest and engaging students in entrepreneurship. The students also demonstrated their intention to undertake another project $(3,69)$.

AWC's overall assessment was also very positive, with a mean of 4.38 for the overall contribution to the project and 4.81 (very high) for indicating the program to colleagues and 


\section{SPIN-OFF FLOURISHING: A NEW WAY FOR ENTREPRENEURSHIP EDUCATION THROUGH \\ EXPERIENTIAL LEARNING PROCESSES \\ DOI: http://dx.doi.org/10.5007/1983-4535.2019v12n3p196}

other students. The negative point is that there was little participation of final project advisors (2.50), although with a high standard deviation. It would be important for the program the greater involvement of the advisors, mainly to help to direct more technical and product aspects.

Table 4 Importance of methods and tools of the Program

\begin{tabular}{|c|c|c|c|c|}
\hline First Workshop: importance of the project & Mean & SD & Answers & Ranking \\
\hline Prototyping, design and startup methodologies & 4,36 & 0,81 & 11 & 1 \\
\hline Competitors and market analysis & 4 & 1 & 11 & 6 \\
\hline Design thinking and user journey & 4,18 & 1,17 & 11 & 5 \\
\hline Entrepreneurs lessons learned & 4,36 & 0,81 & 11 & 1 \\
\hline Investors mindset & 4,27 & 1,01 & 11 & 4 \\
\hline Product fair (last day) & 4,36 & 1,29 & 11 & 1 \\
\hline Monitoring: the importance of mentoring & Mean & SD & Answers & Ranking \\
\hline Weekly meetings on business mentoring & 4 & 0,97 & 16 & 1 \\
\hline Weekly meetings on product mentoring & 3,5 & 1,1 & 16 & 2 \\
\hline Periodic reports about business and products & 2,88 & 1,36 & 16 & 3 \\
\hline Using the AWC blog & 1,93 & 1,1 & 15 & 4 \\
\hline Second workshop: importance to the project & Mean & SD & Answers & Ranking \\
\hline Financing models & 3,94 & 1,2 & 17 & 7 \\
\hline Investment sources & 4,06 & 1,03 & 17 & 5 \\
\hline Crowdfunding, venture capital and angel investment & 4,12 & 1,22 & 17 & 3 \\
\hline Pitch workshop & 3,53 & 1,59 & 17 & 11 \\
\hline Channels, relationship and sales & 3,76 & 0,9 & 17 & 9 \\
\hline Marketing strategies & 3,65 & 1,22 & 17 & 10 \\
\hline Next steps strategy & 4,06 & 1,03 & 17 & 5 \\
\hline Operations and management & 3,94 & 1,06 & 16 & 8 \\
\hline Intelectual property and patents & 4,35 & 0,79 & 17 & 1 \\
\hline Legal aspects & 4,12 & 0,78 & 17 & 3 \\
\hline Investment fair & 4,25 & 1,13 & 16 & 2 \\
\hline Development: AWC importance as a whole & Mean & SD & Answers & Ranking \\
\hline Entrepreneurship workshops & 4,12 & 1,05 & 17 & 4 \\
\hline Business and product mentoring & 4,29 & 1,05 & 17 & 2 \\
\hline Information exchange between teams & 3,63 & 1,26 & 16 & 5 \\
\hline Financing / financial resources offered & 4,18 & 1,29 & 17 & 3 \\
\hline Networking/market access & 4,47 & 0,62 & 17 & 1 \\
\hline
\end{tabular}

Source: Research conducted by the author (2016). 
Table 4 allows the evaluation of the methods and tools used during all phases of the program and the importance of some aspects of the development of students' projects. While many of the evaluations may be related to the quality of the speaker, the analysis is useful.

In the first workshop, all tools were well evaluated, with average scores above 4, with emphasis on prototyping techniques and product design, learning and tips from entrepreneurs, and the product fair on the last day. The lowest score remained for competitor and market analysis. In fact, it was the part where students had more difficulties, even training, and did not have enough time to work.

About the monitoring phase, the weekly business mentoring meetings had a good evaluation, with the highest score $(4.00)$, followed by the product mentoring meetings $(3,5)$. The delivery of periodic business and product reports was poorly rated, with a score below 3 and the highest standard deviation, while the worst importance assessment was for disclosure of the information on the AWC Blog, with a score below 2. The high demand for deliveries and other student activities should explain the lowest grade for the reports. As for the Blog, it was deployed at the end of the program, and really had little use by the students.

Regarding the second workshop, the most important topics and methods for the projects, all with grades above 4, were, in order, (i) intellectual property and patents, (ii) investment fair, (iii) legal aspects, (iv) crowdfunding, venture capital and angel investment, (v) investment sources, and (vi) the preparation of the action plan for the coming months. In summary, the students assessed how important their knowledge of business management and operation, the information they were not accustomed to, besides the plan for the next six months, which has a practical aspect and was already cause for concern and anxiety.

The worst-evaluated item was the pitch/presentation workshop, although with a very high standard deviation. This is not usually a comfort zone for students, but it is critical to brainstorm and gain support and resource from partners or investors. Then the strategies of marketing and positioning, and the strategy of channels, relationship and sales, that could work with more time and in a more interactive way. In more informal dialogues, it became understood that it was because of the quality of the lecture/speaker.

Finally, when evaluating the importance of AWC in general for the development of student projects, the possibility of networking and market access appears as the most important attribute (4.47), followed by business and product mentoring $(4,29)$. The only attribute with a score below 4 , and last place among 5, items was the exchange of information 
between teams. The interaction was better performed in both workshops but did not flow as expected in the follow-up phase, as the teams generally had little contact and made little use of the program's social networks and Blog.

\section{CONCLUSIONS AND CONTRIBUTIONS}

When crossing the results obtained with the data and the theory raised and presented in topic three of the present article, it is perceived that the university's role within the entrepreneurial ecosystem goes beyond the transmission of the theoretical knowledge necessary for the graduation of a student and their training as a professional. It is in the fostering an innovative way of thinking, in keeping with contemporaneity and update to the demanding job market. Although Kolb's work is not recent, dating to the 1980s, his approach remains current, especially as a pillar of programs or projects that seek to develop professionalism, as is the case of the program under investigation.

Specifically about the AWC program, the object under study, when looking at the findings obtained with the survey it is noticed that the program was well evaluated by the participating students, with increased interest and engagement in the final work and in entrepreneurship after the beginning of the program. In addition, connections with foreground have been obtained, both in techniques for generating innovative products and businesses, as well as critical information for operation and management of the business.

With new skills, the students intend to continue with the project, and even in other projects, which shows a positive feeling about the final work. The negative point is the perception of low commitment of the advisor guiding the work, which could contribute more to technical aspects and even of business, considerable point for future editions.

Despite the good dedication to the project, students expressed little importance to formal activities, such as the delivery of product and business development reports, and interaction and exchange of experiences with the other groups through the program's communication channels. On the other hand, the periodic interaction with the mentor and the demonstration fairs was highly valued. Overall, the students greatly valued the networking and the possibility of access to the market through the program. The exchange of information and networking, by the way, were pointed out as the item with the highest initial motivation to enter the program. 
Thus, the article fulfills its objectives of evaluating experiential learning, methods and tools of the AWC Program, contributing to the improvement of the program and inspiring new programs that can use the same methodology for teaching entrepreneurship. As in all scholarly work, some of the perceived methodological limitations were: participant observation per se already has limitations in terms of field research procedures, with the researcher's involvement in the study environment, which may have generated biases; the five-scale survey, despite having achieved a consistent sampling with the study population, did not obtain the number of respondents that can translate into conclusive results, needing a study over the next programs in order to increase the sample and the results can be compared; the particularities of the students involved, all from the exact sciences area, mean that the results can not be generalized to all grades, limiting their findings to the context investigated.

As a recommendation, the program should address an apparent gender imbalance, giving more space and encouraging the participation of the female audience, as well as the distribution between engineering and exact courses, seeking more multidisciplinary teams and different institutions of higher education. As a guide for future studies, the monitoring of different evolutions in the program, as well as an evaluation of the mid-term results of the first groups can be a valid effort to deepen the findings of the results of experiential teaching. Another path that may be covered by future studies is linked to a comparative analysis with other studies on experiential learning and entrepreneurship at university level.

A perceived learning aligned with a placement by Paul Graham, investor and founder of the Y Combinator accelerator in Silicon Valley - reference to the AWC program, reinforced by one of the AWC program's mentors and coordinators: "I now realized that something really changes in the graduation: you miss a great excuse to fail "(GRAHAM, 2015).

\section{REFERENCES}

Blikstein, P (2008). Travels in Troy with Freire: Technology as an Agent for Emancipation. In Noguera P.; Torres C. A. (Eds.). Social Justice Education for Teachers: Paulo Freire and the Possible Dream. (pp. 205-244). Rotterdam, Netherlands: Sense.

Cooper, S., Bottomley, C., \& Gordon, J. (2004). Stepping out of the classroom and up the ladder of learning: An experiential learning approach to entrepreneurship education. Industry and Higher education, 18(1), 11-22. 


\section{SPIN-OFF FLOURISHING: A NEW WAY FOR ENTREPRENEURSHIP EDUCATION THROUGH EXPERIENTIAL LEARNING PROCESSES \\ DOI: http://dx.doi.org/10.5007/1983-4535.2019v12n3p196}

Corbett, A. C. (2005). Experiential learning within the process of opportunity identification and exploitation. Entrepreneurship Theory and Practice, 29(4), 473-491.

Dewey, J. (2009). Democracy and education. 1916.: Watchmaker Publishing.

Endeavor. (2012). O Empreendedorismo nas Universidades Brasileiras. Endeavor Brasil.

Eisenhardt, K. M. (1989). Building Theories From Case Study Research. Academy of Management, v.14, n.4, p.532-550.

Etzkowitz, H. (2011). Stanford and Silicon Valley: The Co-Evolution of Technology Transfer and Regional Absorptive Capacity. Triple Helix IX International Conference. Stanford University.

Feld, B. (2012). Startup Communities: Building a Entrepreneurial Ecosystem in Your City. Ed. Wiley.

Flick, U. (1992). Triangulation revisited: strategy of validation or alternative? Journal for the Theory of Social Behavior, v.22, n 2, p. 175-197.

Hermann et al. Global Startup Ecosystem Ranking 2015. (2015). Retrieved from: http://425business.com/wpcontent/uploads/2015/07/Global_Startup_Ecosystem_Ranking_2015_v1.pdf.

Isenberg, D. (2010). How to Start an Entrepreneurial Revolution. Harvard Business Review.

Isenberg, D. (2011). The entrepreneurship ecosystem strategy as a new paradigm for economic policy: principles for cultivating entrepreneurship. The Babson Entrepreneurship Ecosystem Project.

Kolb, D. A. (1984). Experiential Learning: Experience as the Source of Learning and Development. New Jersey: Prentice Hall.

Kon, F. et. al. (2014). A Panorama of the Israeli Software Startup Ecosystem. Social Science Research Network.

Krakauer, P. V. C. (2014). Ensino de Empreendedorismo: Estudo Exploratório sobre a Aplicação da Teoria Experiencial. Tese de Doutorado. Faculdade de Economia e Administração da Universidade de São Paulo.

Lemos, P. A. B. (2012). Universidades e Ecossistemas de Empreendedorismo: A gestão Orientada por Ecossistemas e o Empreendedorismo da Unicamp. Editora Unicamp.

Levin, J. Venture Capital Heads to Brazil, Defying Economic Slump. Bloomberg Business. (2015). Retrieved from: http://www.bloomberg.com/news/articles/2015-05-05/venturecapital-heads-to-brazil-defying-economic-slump.

Graham, P. (2015) Retrieved from: http://paulgraham.com/mit.html?viewfullsite=1 


\section{SPIN-OFF FLOURISHING: A NEW WAY FOR ENTREPRENEURSHIP EDUCATION THROUGH \\ DOI: http://dx.doi.org/10.5007/1983-4535.2019v12n3p196}

Politis, D. (2005). The process of entrepreneurial learning: a conceptual framework. Entrepreneurship Theory and Pratice, v. 29, issue 4, p. 399-424.

Programa AWC. (2015). Retrieved from: http://awc.institutotim.org.br.

Queiroz, D. T.; Vall, J.; Souza, A. M. A.; Vieira, N. F. C. (2007). Observação participante na pesquisa qualitativa: conceitos e aplicações na área da saúde. Revista Enfermagem da UERJ, Rio de Janeiro, v. 15(2), p.276-83.

Rae, D. (2004). Entrepreneurial learning: a practical model from the creative industries. Education \& Training, v. 46, n 8/9, p. 492-500.

Rae, D.; Carswell, M. (2000). A life story approach in researching entrepreneurial learning. Education \& Training, v. 42, n. 4/5, p. 220-227.

Singer et al. Global Entrepreneurship Monitor 2014 Global Report. (2015). Retrieved from: http://www.babson.edu/Academics/centers/blank-center/globalresearch/gem/Documents/GEM\%202014\%20Global\%20Report.pdf.

Regele, M. D.; Neck, H. M. (2012). The Entrepreneurial Education Sub-Ecosystem in the United States: Opportunities to Increase Entrepreneurial Activity. Journal of Business and Entrepreneurship, Winter, p. 25-47.

Santos, R. V. (2005). Abordagem dos Processos de Ensino e Aprendizagem. Revista Integração. Ano XI, no. 40, p. 19-31.

Solomon, G. T.; Duffy, S.; Tarabishy, A. (2002). The State of Entrepreneurship Education in the United States: A Nationwide Survey and Analysis. International Journal of Entrepreneurship Education, v. 1(1), p. 65-86.

Yin, R. K. (2005). Estudo de Caso: Planejamento e Métodos. 4a. ed. Porto Alegre: Bookman.

Zampier, M. A.; Takahashi, A. R. W. (2011). Competências Empreendedoras e Processos de Aprendizagem Empreendedora: Modelo Conceitual de Pesquisa. Cadernos EBAPE BR, v. 9, Edição Especial, Rio de Janeiro. 